RESEARCH ARTICLE

\title{
Money Walks | The Economic Role of the Street in the City of London 1947-1993
}

\author{
Amy Thomas*
}

Prior to the deregulation of the Thatcher years, the City of London (London's financial district) was largely self-regulated, operating via what Michael Moran refers to as 'an explicit ideology of cooperative regulation', institutionalized within a system of market-specific, club-like bodies, such as the Stock Exchange and Lloyds insurance market. Supervised and operated via its members, the components of each institution were tied together through a mode of exchange that prized faceto-face contact, reputation and trust, epitomised by the Stock Exchange motto Dictum Meum Pactum ('My word is my bond'). The latter was made concrete via messenger-operated payment and clearing systems, organised around the hours of trade, provoking the need for proximity between institutions and specific architectural arrangements and resulting in an urban agglomeration of banks and other institutions in the immediate vicinity of the Bank of England.

The advent of digital technology entailed a decline in the economic significance of pedestrian activity in the City. The shift from manual, paper operations to onscreen transactions made redundant the kinetic network of brokers and messengers that once formed the circulatory system for banking and finance. This paper considers the way in which such shifts ultimately reconfigured the nature of the street as public space and argues that, as fundamental parts of the financial transaction were removed from the City's thoroughfares, the street would no longer be an extension of the workplace, but a space of leisure. Exploring concepts such as 'transaction', 'regulation' and 'exchange' as social processes with material consequences, this paper attempts to chart the historical link between the street and economic activity, through analysis of the City's myriad pedestrian ways and changing attitudes to planning public space in the fifty years following the Second World War.

\section{Introduction}

The dual nature of money, as a concrete and valued substance and, at the same time, as something that owes its significance to the complete dissolu-

\footnotetext{
* Bartlett School of Architecture, UCL, United Kingdom

a.r.thomas@ucl.ac.uk
}

tion of substance into motion and function, derives from the fact that money is the reification of exchange among people, the embodiment of a pure function. (Simmel 1990: 176)

Georg Simmel

To talk of the global economy today is to talk about movement. The rapid passage of capital between financial centres has led to 
analyses of the economy as a 'space of flows' (Castells 1989), and a broader conceptualisation of capital as a kinetic force. In reality, the speed of digital technology means that transactions today are not at all spatial or mobile. Financial markets consist of onscreen changes in title rights, rather than the physical act of exchange, and are reliant upon a host of legal agreements such as labour, debt and investment contracts and many more. The fiction of mobility provides a mode of diagramming this process, yet causes it to be abstracted from its material reality.

The process of exchange continues to be dependent upon people and places. New financial centres are emerging all over the world in ever grander and more iconic forms, whilst old ones consolidate their presence with novel additions to their skylines. However, the advent of mobile technology and the expansion of the Internet in recent years have ensured that the material relationship between exchange and place is less obvious. Historically, the transaction was reliant upon the movement of people and paper in space (whether in the market, the square or the street) and was carried out in concrete places. Urban places could, therefore, be more readily understood as material components in the complex process of financial exchange, unlike the symbolic role the skyscraper has for the global economy today. Georg Simmel's conception of money, as 'the reification of the pure relationship between things as expressed in their economic motion', seems an appropriate metaphor (Simmel 1990: 176). The financial centre, as a tangible object, has, like money, become the material symbol of the contractual relationships between people as expressed in their economic motion'.

This paper explores the relationship between transaction and place through an analysis of the changing economic role of the street in the City of London in the fifty years following the Second World War. Unlike the exchange or marketplace, the street is a material element of economic activity that is often overlooked on account of its 'inbetween' position, despite playing a fundamental role in the financial community prior to the digitisation of trade. Furthermore, the connotations of movement associated with the street, the road and the pedestrian way in the financial context, go some way to explaining our contemporary fascination with economic 'flows'.

The following discussion considers the role of the street, alley and pedestrian way in the shifting context of financial practice via an analysis of the more mundane daily activities in the life of one of the world's leading financial centres, the City of London (hereafter 'the City'). The advent of digital technology entailed a decline in the economic significance of pedestrian activity in the City; the shift from manual, paper operations to onscreen transactions made redundant the kinetic network of brokers, messengers and bankers that once formed the circulatory system of the City. This paper considers the way in which such shifts ultimately reconfigured the nature of the street as public space, arguing that, as fundamental parts of the financial transaction were removed from the City's thoroughfares, the street would no longer be an extension of the workplace, but a space of leisure.

\section{Transactional channels}

Owned and administered by an independent municipal authority known as the City of London Corporation, the City is a juridically distinct enclave within Greater London and the UK, physically contained to little more than a 'Square Mile'. Officially 'apolitical', the relationship of the Corporation with the British government has been complex. The Corporation has existed since before Parliament, and is known for its host of ancient ceremonies and peculiar range of institutions, such as the livery companies and its Lord Mayor. It is also the only political constituency in the country in which businesses form the majority of the electorate - a practice that was outlawed elsewhere in Britain in the local government Act of 1963. It has 
historically emphasized its right to independence from the state, and today retains the only non-parliamentary representative allowed into the Commons Chamber: the Remembrancer, a lobbyist for the financial services industry, charged with protecting the City's rights and privileges (City of London Corporation n.d.).

As the former commercial heart of the British Empire, the City was a concentrated example of the networked society that had ensured the dispersal of privilege in Britain and in the colonies for centuries. Defined by its gentlemanly code of conduct, epitomised by the Stock Exchange motto 'Dictum Meum Pactum' ('My word is my bond'), the dense web of specialist financial sectors that clustered within the boundary of the City were linked by functional and familial networks, assisting an informal method of self-regulated business practice that was unique to Britain. Michael Moran defines the latter as 'an explicit ideology of cooperative regulation', unique in its formalisation of its seemingly informal institutions into a collection of club-like establishments, such as the Stock Exchange, the Baltic Exchange and the Corporation of Lloyds, around which the City would operate (Moran 2003: 2).

Within the City, the components of this system were linked through financial, social and spatial operations that necessitated proximity. For example, all Stock Exchange member firms were required to keep offices within seven hundred yards of the Exchange itself in order to take advantage of its centralised settlement system (Thrift 1994: 343), whilst all of Lloyds' member brokers were encouraged to base themselves in the immediate environs of the insurance market to facilitate the spread of information. Beyond the confines of the contained markets, there were also the exchanges occurring between institutions, most notably the banks, of which the clearing banks, discount houses and merchant banks formed an important triumvirate geographically linked through Town Clearing (Courtney and Thompson 1996: xvii).
Unlike the digital clearing systems used by banks today, up until the late twentieth century, the settlement of accounts between two parties in the City was a physical act, carried out via messengers and choreographed according to a precise timetable. The process was separated into three independent systems: General Clearing, 9.15-10.30am; Town Clearing, 2.30-3.45pm; and Cheque Clearing, a system initially dealing with the payment of salaries. All three were operated via the Bankers' Clearing House, the institution at the heart of the clearing system, to which all cheques were sent for payment. Situated in the midst of the banking area on Lombard Street, the Clearing House remained empty for large periods of the day, standing in the form of a small classical building, seemingly incommensurate with the 2-3 million payments that would be processed there daily - the result of its time-specific functionality (Economists Advisory Group 1971: 282).

Town Clearing was the most important for institutions in the City as it was the only way of processing high-value same-day payments, and thus involved nearly every institution in the City. Town Clearing required its members to reside in the Town Clearing Area, namely the half-mile radius of the Bankers' Clearing House, for reasons of expediency (Hailey and Wanley 1973). ${ }^{1}$ Operated by messengers who would bring the total number of cheques accrued by their bank to the Clearing House at the end of the day, the system dealt with high-value transactions that had a quick turnover time: a cheque between two town branches received at 3pm would be cleared the same day; consequently the speed and efficiency of the system was of vital importance to the money market (Economists Advisory Group 1971: 280). The result was a highly mechanised process, orchestrated by a computing army of female clerical staff who were trained to process a minimum of 2,000 payments per hour and served by hundreds of messengers moving rapidly through the City's streets at specific times of the day (Battersby 1964). 
Prior to the automation of clearing and settlement procedures, the labyrinthine web of alleys and cut-throughs within the Town Clearing Area formed an integral part of this transactional process. Their role as channels for capital had emerged from the activities of the merchants and traders of the seventeenth and eighteenth century, for whom the alleyways and courtyards surrounding the Bank, the Royal Exchange and Lombard Street comprised the circulatory system for the anatomy of finance and trade, permitting face-to-face interaction and rapid communication between the various commodity markets located in the coffee houses buried deep within the blocks. Despite some sizeable infrastructural developments and building booms in the nineteenth and early twentieth century, this tightly wound system of passages and precincts were for the most part retained to assist informal patterns of exchange as well as the settlement process that had grown in scale and complexity with the rise of Britain's imperial earnings.

The physical and economic devastation caused by both World Wars in the first half of the twentieth century seemed to increase the importance of preserving and reinstating the City's smaller streets to facilitate the rebuilding of markets. The latter was highlighted in post-war planning policy. William Holford and Charles Holden's 1947 plan for rebuilding the City embraced the City's 'private circulation', proposing a network of pedestrian precincts connected by the existing alleyways and courtyards (Holden and Holford 1951: 231-264). 'There is, of course, even a functional pattern in the ant-heap', they argued, 'the planner's problem is to make this pattern more efficient' (Holden and Holford 1951: 232). Efficiency was to be met with greater provision for pedestrians, including: 'increased open space, generally in small patches'; the linking up of such areas with 'shopping centres, historic buildings, and open viewpoints by means of wider pavements [...] or tree planted streets [...] or in some cases subways under traffic crossings'; the construction of shopping arcades in Leadenhall Market and Old Broad Street, and in some of the sunk roundabouts [...] where small purchases can be made on the way to and from railway stations and during the lunch hour'; the closure of certain streets to all but service vehicles; and the widening of pavements (Holden and Holford 1951: 289).

The large-scale incendiary bombing during the Blitz had destroyed some 26.8 million sq $\mathrm{ft}(31 \%)$ of the 85.8 million sq $\mathrm{ft}$ of office space in the City (City of London Department of Architecture and Planning 1976), most of which the Holden and Holford proposal sought to rebuild. ${ }^{2}$ After the delivery of public spaces, roads and infrastructure, the report calculated the required office floor space area to be approximately five times that of available building sites, and subsequently enforced the first plot ratio regulation of 5:1 for all new developments, which was strictly implemented until it was abolished in 1994 (Holden and Holford 1951: 301). Where the London Building Act had formerly placed restrictions on the height of a building, the new law placed limits on the total area of a given building in relation to its site.

The high demand for office space within the Town Clearing Area was acknowledged in the report by increasing the plot ratio to 5.5: 1 in the half-mile radius of the Bank of England (Holden and Holford 1951: 302). The lack of floor space in the area meant that office buildings were often buttressed up against each other, and consequently built with myriad passages running through and between them in order to allow access for those who worked deep within the block, and to conform to the new daylighting code as set out in the reconstruction policy. Acting as convenient short-cuts, these narrow, interlaced channels turned the messengers' daily clearing walks into occasions for opportunist espionage, as they walked past offices, overhearing conversations and meeting other messengers on their daily rounds (Courtney and Thompson 1996: 205). Similarly, for those who were known 
by the gatekeepers, it was even possible to take a shortcut right through the Bank of England's seemingly impenetrable fortress walls, from Bartholomew Lane to Princes' Street (Hennessy 1992: 338).

\section{The street as a mode of economic regulation}

The manual clearing systems had helped to keep the City's self-regulatory practices in place, reinforced by the Bank of England's supervision. Acting as a porous barrier between Westminster and the Square Mile, the Bank and its workforce comprising many former City executives, had emerged during the nineteenth century as the central regulator for the City due to its development into the central bank. As Michael Pryke notes, this regulation expanded into the physical realm of the Square Mile, as the City's built form had effectively developed around the Bank of England, placing it at the core of a precisely orchestrated spatio-temporal system, revolving around the hours of trade, settlement and clearing times, and the changing Bank Rate (Pryke 1991: 204). This was enforced through the imposition of spatial rules to which all companies and institutions had to conform, the most important being the insistence on the close proximity of all banks to the Bank of England to facilitate supervision and its own centralised settlement system, which it operated in its capacity as the 'banker's bank' (Pryke 1991: 204).

The village-like social structure and isolation of the financial core of the City had intensified in the post-war period, arguably in response to the increasing interference of the state in City affairs. The encroachment of the government - which had necessarily tightened its grip on the City following the collapse of the Gold Standard in 1931 and in the financially demanding years leading up to the Second World War - culminated in the nationalisation of the Bank of England in 1946. This transition reinforced the dual nature of the Bank as regulator of, and spokesperson for, the City. Acting simultaneously as the City's and the Government's representative in each territory, the Bank was effectively 'an interface between the state and the market' (Burn 1999: 241).

The modus operandi in the City reflected the prevailing Keynesian approach to economic policy of the post-war period: namely, that the most efficient way to stimulate economic growth and curb inflation was by controlling demand via the state. In theory, this could be done through two agents: central government, which would use taxes and public spending to affect productivity; and the central bank - the Bank of England - which could control interest rates and therefore the supply of money in the system, acting as a kind of monetary pump. In addition to keeping the accounts of the Exchequer and other government departments, and acting as a registrar for all quoted Government securities, the Bank was responsible for controlling the money supply via its activities in the money markets - namely, the discounting of commercial bills. The latter was executed via an intermediary agent known as the Discount Houses: if the Bank wanted to inject money into the market it would buy commercial bills from the Houses; if it wanted to drain money it would sell bills (Ferris 1960: 72).

The Discount House brokers were required to be extremely knowledgeable about the state of the market and, as such, they would spend the first part of the morning making the rounds on foot to relevant banks and institutions in the City, which on a good day could total in excess of 100 visits (Ferris 1960: 62). Sociability was essential and the oral contract was sacrosanct, as most transactions were not finalised on paper until the end of the day (Ferris 1960: 62-63). As the mediators between the Bank and the market, the Discount Houses were granted privileged access to the Bank's fortress via the Discount Office, known in the City as 'eyes and ears of the Bank', or 'the window in the windowless wall' (Pryke 1991: 205; Kynaston 2000: 56). Each morning, the manager of each Discount House would visit the Discount Office to give 
the Bank the general 'feel' of the market, so it knew how much money to pump into the system (via the minimum lending rate of Treasury Bills - effectively an equivalent of setting interest rates). The Bank would then communicate the decision to buy or sell via an individual known as the special buyer, or "hidden hand"' (Ferris 1960: 72). The economic purpose of this ritualistic process was to keep money in constant circulation and avoid the idleness of spare cash. Indirectly, the system also facilitated the territorial persistence of tradition that had ensured the reproduction of the City's impermeable culture for centuries.

\section{New markets, new solutions}

Within the next decade, an increased rationalisation of economic modelling and financial practices began to break down the synergy between the City's informal geography and its informal mode of transaction. A scientific overhaul of the mechanisms of the financial system took shape throughout the 1960s: the rise of 'the analyst' meant that banks were increasingly using statistics to assess the state of the market as opposed to the biographical information and reputation of companies, merchant banks moved beyond their purely advisory capacity to become specialists in takeovers and mergers, and the Stock Exchange introduced an examination for potential new brokers for the first time in its history. This process of rationalisation was a response to broader shifts that were taking place in the context of international finance, which would eventually eradicate the City's territorial practices.

For the last two decades, Britain's Keynesian approach to policy had been centred on preserving currency stability. Maintaining the strength of Sterling was, of course, partly ideological as the Sterling Area - Britain's empire-based currency zone - represented Britain's last stronghold over its imperial dominion, which the Bank's socio-spatial supervision in the City had helped to maintain. However, the 1960s saw the emergence of the Eurocurrency markets, London's first offshore currency markets, as well as a new set of money markets in Local Authority Loans and Inter-bank lending that operated outside of these parameters. The new money markets dramatically altered the spatial operations of the City. The development of the Euromarket, followed by the emergence of a highly lucrative Eurobond market, resulted in a dramatic influx of international business, with the number of foreign banks in the City doubling from 77 in 1960 to 159 in 1970 (Kynaston 2000: 501). The shortage of floor space in the historic core and the growth of firms forced companies to seek accommodation beyond the traditional heart of the Town Clearing Area (Kynaston 2011: 404).

In addition, the mode of exchange itself was beginning to change. For the first time, the Interbank markets permitted banks to lend unsecured (i.e. without the liquidity to back up the deal), a concept that was seemingly anathema to the City's Dictum Meum Pactum ethos, relying on the creditworthiness of the individual. The increasingly abstract and speculative nature of these new financial instruments ensured that the quantity of transactions was much higher than the quantity of final payments made, thereby creating a distortion between the spatial act and the transactional process on account of the incompatibility of their relative speeds (Economists Advisory Group 1971: 297). ${ }^{3}$ Initially, this increased speed was predominantly facilitated by telephone trading, which still necessitated proximity between institutions for the final settlement of accounts between parties, as well as unofficial visits to the banks to assess the state of the market, and the Bank's own mode of intervention through the discount houses. However, in line with the evermore scientific approach to financial practices, throughout the 1960s there were efforts to begin to automate the paper system, a development that was assisted by the passing of the Stock Transfer Act in 1963, ensuring that certificates no longer needed to have a buyer's 
name on a form, and thus eliminating the necessary individualisation of every transaction (Kynaston 2000: 139).

The impulse behind automation was largely for reasons of economy and efficiency. By the end of the 1960s a number of financial institutions had invested in computers as a way to counteract the shortages of clerical labour, wage increases, and increasing space restrictions following the first building boom (Economists Advisory Group 1971: 276). The innovations during the 1960s were predominantly process-driven, aiming at reducing the costs caused by human processing speeds and the time spent correcting errors and inaccuracies in the paper system (Smith 1970: 926). America and its financial centres provided the inspiration for many of these improvements, which had been at the forefront of computing solutions since producing the first digital computer in 1940 (Batiz-Lazo and Wood 2002: 9). The Bank had sent members of its Accountants Department over as early as 1955 to review 'business machine equipment', and most computers acquired in the City throughout the 1960s were manufactured by American companies (Bank of England 1955; BatizLazo and Wood 2002: 9).

The impetus for innovation in both New York and London was not so much the transaction time itself, but rather that every institution was obliged to know the precise location of each certificate, as well as the status of accounts, at any given moment. The latter was made increasingly difficult with the rise in the number of transactions that emerged with new and expanding markets, and the ever more complex methods of processing, which required each paper certificate to pass through a vast number of hands. As a commissioner of the Securities Exchange Commission in New York wrote in 1970, in the case of stock certificates alone, each piece of paper would go through around 14 different processes and over four 'street carries' in the space of a few days, passing through 'the branch office, the receiving department, the transfer analyst, the transfer department, the receiving department and the delivery department' (Smith 1970: 926). Following this, the certificate would have to be packaged and sent to the transfer agent (where it would be handled by four different people: the window clerk, transfer analyst, examiner and cage clerk), before going through the typing, proofing, balancing and sorting departments, after which it would be sent to the registrar to sign the certificate by hand. Following this, it would be sent back to the transfer agent and then back to the original brokerage house for it to be logged once more, and then sent to the receiving party (broker, bank or individual) if necessary (Smith 1970: 927).

While the City had its own idiosyncrasies, the journey of the stock certificate or other bill was similar in its geographical scope to that of New York, and with the number of articles cleared annually at the Bankers Clearing House rising from 397 million in 1958 to 854 million in 1968, the system was becoming increasingly clogged and subject to error (Economists Advisory Group 1971: 278). Solutions such as punch card systems and magnetic ink, and even the use of CCTV for document transmission, were introduced to assist the centralisation of clearing systems by 'netting' balances against each other in electronic form and thereby limiting the amount of paper moving around the City (Economists Advisory Group 1971: 239). In 1960, the Stock Exchange settlement department was mechanised, with 18 machines installed to carry out the activities previously carried out by 150 workers, whilst the Bankers' Clearing House acquired new cheque sorting machines to manage the increasing amounts of paper flooding in with the new markets (Progress and Tradition: Electronic Robots 1960). The latter required cheques to be in strict order and as such to be delivered in boxes, loaded into trollies and then transported by vans. Due to the lack of access to the Clearing House on its cramped Lombard Street site, special electric vehicles, 
akin to small milk floats and designed to be quiet, were developed so as not to disturb surrounding offices. At one point the street was even paved with rubber blocks to dampen the noise (Cheque and Credit Clearing Company n.d.; Economists Advisory Group 1971: 280).

Despite advances in technology, the dominance of pedestrian trading activity in the City prevailed until its digitisation in the 1980s. However, much like attempts at financial automation, the City's planning department, for the first time in its history, took steps to actively programme pedestrian activity in the City. In 1967 and 1969, two major surveys were conducted by the Corporation to calculate the movement of office-workers throughout the Square Mile. ${ }^{4}$ The surveys represented a general mood in urban planning that viewed pedestrian freedom as the mark of a civilised city, and traffic as the enemy. The growth in car ownership throughout the 1950s and 1960s had given rise to an anxiety surrounding congestion and collision in the urban realm, as well as to a planning rhetoric that favoured the segregation of pedestrians and cars. At the regional level, this was implemented via decentralisation policies and the construction of satellite towns such as Croydon to stem the build-up of traffic in the city centre. At the urban scale, segregation was to be based on the Corbusian model, with planners such as Sir Colin Buchanan propagating the division of the city into raised pedestrian walkways with motorways below (Buchanan and Crowther 1963). It was from within this context that the Corporation momentarily implemented a scheme, which, if completed, would have been the most radical infrastructural programme in the history of London ever to be built: the Pedway, a 30-mile network of raised walkways covering the Square Mile.

Unsurprisingly, the concept of vertical segregation in the City did not emerge from the Corporation's conservative planning personnel (under the auspices of the City Engineer), but from the more radical London County Council (LCC) Architects' Department (Hebbert 1993: 435, 440). Whilst most of the City's planning decisions had been transferred back to the Corporation by 1955 , after a brief spell in LCC hands during the post-war period, the scale of bombsites in Paternoster Square and the Barbican necessitated a collaborative approach to redevelopment between the two municipalities. These vacant sites presented themselves to the LCC as opportunities for experimentation with 'three-dimensional planning' via raised walkways (Hebbert 1993: 435). Although, as Michael Hebbert points out, this collaborative attempt was not without conflict, since 'the corporation's natural preference was to reinstate and widen the old street pattern, parcel the land into standard frontages, and sell them off to developers' (Hebbert 1993: 441), by 1959 the LCC had convinced the Corporation's Common Council to enshrine the separation of pedestrians and vehicular traffic in policy, and the construction of highlevel walkways became a priority in City planning (Hebbert 1993: 441, 443).

The full extent of the City's plans for the Pedway were kept secret until the mid1960s and not released publicly until 1976, at which point the scheme was under threat from conservationists. ${ }^{5}$ However, the plan was implemented wholeheartedly throughout this period, and openings and connections for the pedway network were incorporated within most commercial developments throughout the next decade. This was in part due to the fact that developers would be offered incentives for their inclusion into schemes, usually in the way of plot ratio concessions, and were permitted to use the connection platforms for temporary offices, thus producing additional revenue. ${ }^{6}$ The enthusiasm with which the network was implemented was justified by reasons of economy and efficiency in the financial centre. 'Business activities carried out within the City [are] known to be based on a long tradition of personal contact', claimed the 
scientific 'Walkways Study', which sought to legitimise the scheme through further analyses of 'pedestrian and vehicular movement patterns, land use and activities, and physical development' (City of London Department of Architecture and Planning 1978: 29).

Viewed as an efficient alternative to, what City Architect Edwin Chandler described as, the City's 'utterly impracticable' alleyways, the walkways were constructed in parallel to the designated traffic routes (Chandler 1975: 91). Road widening, construction and largescale demolition took place throughout the City, attracting vociferous protest from conservationists, which, alongside the unfeasible cost of maintenance, would ultimately succeed in halting the pedway project. 'It is a very dangerous thing to create a situation where you forget the prime function of the City and think of it in terms of a nice 'olde worlde' tourist attraction,' Chandler argued in his defence; 'the fact remains that if you want something that is efficient as a great financial centre then it is almost impossible to carry it out on a major preservation basis' (Chandler 1975: 91). Despite Chandler's petition, in 1978 the scheme was reduced to a 'Minimum Network', comprising existing sections that might have been made viable with the additions of links and bridges. However, by the time of the building boom of the 1980s, barely a fraction had been completed.

\section{Dematerialisation and the deregulated City}

The transition to the fast-paced Thatcherite City occurred slowly and somewhat awkwardly throughout the following decade. The gradual concession of the government to the markets saw a shift in political ideology from the state allocation of funds to that of a market economy, positioning the paternalistic traditions of the City under scrutiny from neoliberal politicians. It was during this period that the Bank's regulatory web began to fall apart, as more expanding City institutions made requests to move beyond the traditional banking district to the north of the City, south of the river and, more worryingly, to the West End and Mayfair (Pryke 1991: 209-10). Furthermore, the absorption of computer technology into most offices brought a shift in pace that was entirely incommensurate with the City's face-to-face operations.

Initially there was a general reluctance to abandon much of the old City's ceremonial conduct, with persistent participation in activities such as the visceral spectacle of messengers running to and from the Bank every Thursday to communicate the Bank Rate, notwithstanding a fully operational CCTV network (Economists Advisory Group 1971: 295). ${ }^{7}$ Despite the increased automation of clearing systems and rise in telephone usage, the fact was that, even into the 1970s, many firms preferred to retain the human infrastructure of the traditional messengeroperated clearing systems in order to retain the social structure and security that came with it. 'One of the reasons people had concentrated in the Square Mile was so that they could be part of this system,' stockbroker Nick Durlacher recalled; 'messengers were an important part of all City businesses. [...] I have a feeling that [they] may have been more secure than the electronic technology we have now which can be hacked into' (Courtney and Thompson 1996: 205).

Aside from the threat to the City's value system, founded upon face-to-face meetings and ritualistic displays of kinship, there were concerns surrounding the economic viability of electronic methods (Economists Advisory Group 1971: 296). The pace of the paper system, which had emerged due to the geographical organisation of the City, had become so ingrained into operations of the economy that faster technology initially seemed problematic. Despite the potential profitability of quicker settlement times with computer-run settlement systems, it was feared that 'if any improvement is achieved in the speed of payments transmission [...] they will be faced with a loss of the interest 
normally earned on money in the course of collection', which for cheques could take up to three days (Nevin 1970: 209). Much in the way that the pedways had threatened the spatial practices of the club network through geographical distortion, the electronic payment systems threatened this system through temporal distortion (Pryke 1991: 203).

The question remained, how could an electronic programme reproduce the selfregulatory club-like arrangement that had for so long protected the City's independence? The first form of electronic transfer system of payments, known as 'BACS' (Bankers Automated Clearing System), was developed between clearing banks in 1968. However, it was not until 1972 that attempts were made to devise a system to accommodate the high-value, same-day settlement in Town Clearing. ${ }^{8}$ One early prototype developed by the Interbank Research Organisation (IBRO), named SOVEREIGN, had been conceived to emulate the spatial form of town clearing, which, it argued, had been 'developed to fit the requirements of their users, the convenience of their operators and the restrictions of their geography' (Hailey and Wanley 1973).

The hypothetical payment system was designed as an electronic version of the City's club-like organisation: a member-run scheme that was centrally overseen by the Bank of England, mimicking the existing socio-geographical arrangement of the City as it currently stood. Those who wished to use the system were obligated to be 'members of a suitable club', as the clubs provided 'services to their members by accepting and retransmitting their messages, by acting on the contents of the messages and by vouching for the good standing of their members' (Hailey and Wanley 1973). The 'clubs' would be digital versions of existing institutions such as Lloyds and the Stock Exchange, acting as informal modes of surveillance to ensure 'the authenticity, credit worthiness, honesty and integrity' of each 'player' in the payments game (Hailey and Wanley 1973). Although this plan was never executed, the official system CHAPS, which was implemented in 1984, was initially conceived as a member-run scheme that would reproduce the existing geographical arrangement, providing settlement for offices within a onemile radius of the Bankers' Clearing House in Lombard Street - the 'CHAPS area' (Hailey and Wanley 1973).

Within the following five years, the gentlemanly practices in the City would be rapidly subsumed by an uncompromising deregulatory impulse underpinned by monetarist experimentation. The power cuts, three-day week, high unemployment and uncontrollable inflation that had plagued the Heath government in the middle of the decade were met by an IMF rescue operation in 1976, bearing the caveat of adopting monetarism as an economic model. Now the money supply, not the state allocation of funds, was the primary concern, and the City, [being] in the business of moving and making money, was always likely to be more sympathetic to the notion that money matters in economic policy' (Smith 1991: 81). The Bank embraced monetarism, adopting the ideas of Milton Friedman and the Chicago School even before the Treasury, and, as economic historian David Smith argues, 'in the 1980s, [it occasionally] appeared to act as the Treasury's monetarist conscience' (Smith 1991: 81).

The new scientific approaches to economic analysis ensured that an equally rationalised and methodical approach to regulation and operation be adopted by the City Establishment. The closure of the Discount Office in 1976 ensured that the Bank's mode of supervision as 'a by-product of the market intelligence fathering operations of its Discount Office' was replaced by the creation of a specialist Supervision Division (Moran 2003: 75). The secondary banking crisis of the 1970s had destroyed a number of smaller banks and threatened the elites, leading to the enforcement of the Banking Act 1979. The Act ensured that banking supervision became codified in law, that all regulatory bodies were to report to central government, and that the Bank of England's role as a 
regulator of the City was enshrined in statute (Moran 2003: 75).

The dissolution of the Bank's spatial and visual mode of regulation was exacerbated by the influx of international businesses. With the abolition of the post-war exchange controls in 1979 and the subsequent deregulation of the stock market in the Big Bang of 1986, the number of foreign banks in the City continued to increase, with requirements that exceeded capacity of the dark, cramped, and often listed Victorian and Edwardian properties in the Square Mile. The need for large floor-plates and cavities to support the wiring and cooling of computers, and increased volumes of unrestricted trade, led to a loosening of planning restrictions that would allow businesses to move beyond the historic core to accommodate larger architectural footprints. By the 1980s, the impact of financial deregulation had spread to the geographical arrangement of the City: a host of new developments emerged at the peripheries to attract and accommodate bigger international corporations, forming new financial villages based on American prototypes more suited to the needs of its transatlantic tenants.

The dispersal of offices, in tandem with the increases in volume and scale of financial transactions, were the dominant impetus for the implementation of the CHAPS system in 1984. However, it wasn't until 1995 that Town Clearing officially ended and the final 'dematerialisation of money market instruments' finally took place (Bank of England n.d.). The pedestrian system persisted alongside CHAPS for several years, partly out of habit, partly due to the belief that the efficiency of the old system would render the economic benefits of automation too insignificant to bother (Clark 1984: 36-7). It was the perceived risk of human error in the old system that finally put an end to the employment of messengers for clearing and settlement in the City. In May 1990, a financial messenger was robbed at knifepoint of $£ 292 \mathrm{~m}$ worth of bonds he was delivering in a City side street, at which point the Bank of England switched its Central Moneymarket Operations office to a digital system entitled CREST (Bank of England n.d.; Dennis 2002).

In the aftermath of the Big Bang, the City's planning policies became more focused on the provision of space than the facilitation of movement. Despite protests from conservation groups, by 1986 the City's Local Plan was redrafted to allow for the demolition of once "listed" historic buildings to expand its floor space by 25\% (King 1990: 91, 98). The upper level policies of the 1970s, centred around the pedways, were almost entirely abandoned in favour of policy that catered for the construction of enormous developments using the Corporation's newly acquired 'airrights' to span roads and railway tracks. With technological innovations increasing transaction speeds, and the replacement of the old City's gentlemanly codes of conduct with a new international variant of business etiquette, the streets and alleys were stripped of their functional purpose and given a new sartorial role as the backdrop to the theatre of haut finance.

This new role was taken seriously by the Corporation. The impact of the conservation lobby a decade earlier had ensured that, despite its more pragmatic impulses regarding property development and demolition, the historic face of the City's streets and courtyards had become a key part of the City's branding strategy as an international financial centre. By the time of the publication of the Draft Local Plan in 1984, pedestrian movement had been removed linguistically from the realms of business efficiency and repositioned within two additions to the City's planning lexicon: 'townscape' and 'environmental quality' (City of London Department of Architecture and Planning 1984: 139-174).

Introduced for the first time in 1979, the term 'environmental quality' was defined as the 'degree of pleasure or displeasure experienced in living and working in, and in moving about, the City of London'. 'While the design of individual buildings is important', 
the 1979 'Background Study' claimed, 'so is the treatment of the spaces between and the settings within which they are seen' (City of London Department of Architecture and Planning 1979: 11; 43). Far removed from the statistical emphasis in the pedestrian and meeting surveys just one decade earlier, here the City's 'distinctive urban form and "grain"', 'close-knit building pattern' and 'strong general sense of enclosure' would now provide spaces of entertainment between office hours, as opposed to functional appendages to the workplace (City of London Department of Architecture and Planning 1984: 146). By the beginning of the 1990s, the conservationist attitude had been wholly subsumed within the City's broader business strategy to reinstate itself as the world's leading financial centre. ${ }^{9}$ Throughout the decade, a number of alleys, such as Pope's Head Alley and Ship Passage, were realigned or reinstated on account of the fact that 'the relatively short walking distances between firms, institutions and other services located in the City is seen to form a unique and valued feature of the City's business environment' (City of London Department of Planning 1995: 81).

\section{Conclusion}

By the end of the twentieth century, the role of the street in the City had been radically reconfigured. The terrorist bombings of the Provisional Irish Republican Army in 1992 and 1993 demanded a re-writing of the City's approach to security, public space and pedestrian access. Checkpoints positioned at the entrances to the Square Mile stemmed the flow of traffic, indirectly placing the focus on pedestrian activity once more, yet the introduction of over 1,000 private surveillance cameras by 1996 ensured that this activity was to be heavily monitored (Coaffee 2009: 115). Simultaneously, the discussion of streets in planning terms had shifted away from connotations of economic pedestrian efficiency, towards a conception of the street as public space designed to facilitate the social accoutrements of the financial services industry. In other words, the street moved from being an extension of the office, to a place devoted to leisure.

This paper has attempted to reveal the historical relationship between the street and economic activity in the City as a reciprocal process. Prior to automation, the fine mesh of smaller streets was both the product of mercantile and financial activity, and the catalyst behind the geographical arrangement of the clearing system. In regulatory terms, the streets assisted a form of natural surveillance via a kinetic fraternity of messengers, whilst the movement of the discount brokers between institutions permitted the Bank to act, oversee and, if necessary, intervene in the money markets. Throughout the process of automation in the 1960s and 1970s, the conflict between the speed of interpersonal and electronic modes of exchange meant that the street became the subject of experimentation for economic gain. In planning terms, the Corporation looked for efficiency via wholesale reconstruction of the pedestrian network above ground; whilst simultaneously at ground level, attempts at centralisation and new inventions in the clearing systems were implemented to mechanise the existing spatial process. This temporal incongruence between pedestrian pace and digital technology grew with the development of digital technology. The latter was revealed in prototypes for the automated clearing systems in the 1970s, in which the club-like social and spatial arrangement of the City was used as a basis for the organisational structure of the new, digital systems.

The gradual disintegration of the overt economic function of the City's streets has come about with the growing abstraction of financial instruments and increased mobility of the labour market. However, that is not to say that the role of the street has diminished, but has taken on a different meaning; the City's historic streetscape now forms the setting for out-of-hours entertainment for workers, and simultaneously behaves as a branding mechanism to attract new workers and businesses to the City. Today the physical 
limitations of finance persist; geographical proximity of institutions can have microsecond advantages in the context of high frequency trading, causing many firms to 'cluster' in the same area (Mollan and Michie 2012: 36). ${ }^{10}$ As Simon Mollan and Ranald Michie have argued, "there has been no "end of geography" or "death of distance" because time is relative when dealing in financial products where margins depend on fractions of a second when orders are placed' (Mollan and Michie 2012: 38-39). Simultaneously, the face-to-face business 'meeting' continues to take place, despite improvements in technology, rendering the City just as important as a place as it is a financial centre.

The emphasis on the mobility, invisibility and flexibility of the current global financial arrangement only serves to reinforce its impermeability to those outside the system. Aesthetically, such assumptions ignore perhaps the biggest environmental paradox of financial capitalism: as the mechanisms of exchange become increasingly invisible, the environment that supports such processes, i.e. the financial center, is made increasingly visible. This paper has attempted to show that financial activities are reliant on the relationships between individuals, places and spaces and thus cannot be written off as abstract automaton, when the financial transaction is in fact a process that underpins the basis of society. As Simmel so eloquently wrote, over a century before us:

It is [...] almost a tautology to say that exchange brings about socialization: for exchange is a form of socialization. It is one of those relations through which a number of individuals become a social group, and 'society' is identical with the sum of these relations (Simmel 1990, p. 175).

\section{Notes}

${ }^{1}$ There was a subset of Town Clearing that dealt with settlements for non-clearing banks and businesses located outside of the Town Clearing Area known as 'Walks Clearing'. The latter were carried out by special messengers using carts.
2 The 1947 plan accommodated for a future daytime population of 427,000 (which was far higher than ever realised), over 82 million sq. $\mathrm{ft}$, dispersed across a smaller area of land than that used by the City in the pre-war period (Economists Advisory Group 1971: 46).

${ }^{3}$ For example, in May 1968 the Bank of England allowed the discount houses to deal as principles in bills of exchange in foreign currencies, and just two years later, the members of the Union Discount Company were carrying walkie-talkies on their daily visits (Kynaston 2000: 504).

${ }^{4}$ These were titled the 'Business Contacts Survey' (1967) and 'Pedestrian Movement Survey' (1969). See, respectively: Economists Advisory Group (1971): 161-168; and City of London Department of Architecture and Planning (1978): 21-24.

${ }^{5}$ See 1976 Pedway map in City of London Department of Architecture and Planning (1978).

${ }^{6}$ Doubts about the Corporation's ability to enforce such planning conditions in the more official capacity of planning permissions led to the passing City of London Various Powers Act (1967), which effectively stated that Walkway provisions were compulsory for new schemes falling within the network, but that maintenance would be provided for by the Corporation (Great Britain, 1967).

7 The report quips, 'like the traditional top hat, [it] is little more than a gesture. Firms admit (a little shamefacedly) that they get the news quicker by closedcircuit television' (Economists Advisory Group, 1971).

${ }^{8}$ Clearing banks became known as retail banks in 1973. Non-clearing banks were able to use the system but only through using a clearing bank as an intermediary (Batiz-Lazo and Wood 2002: 11).

${ }^{9}$ For more on the City's self-conscious planning policies, see Kaika, 2010.

${ }^{10}$ City trading desk transactions with the London Stock Exchange servers located in the City was achieved in $0.1 \mu$ s, while 
connection to the NYSE Euronext site in Basildon took $0.43 \mu \mathrm{s}$, and connection with the Chi $\mathrm{X}$ server in Slough took $0.47 \mu$ s. These time advantages, however small, are important.

\section{References}

Bank of England 1955 Accountant's Department File on Mechanisation: Visit to the United States (US) by the chief accountant to review business machine equipment.

Bank of England n.d. 'Market Operations Timeline' [WWW Document]. URL http://www.bankofengland.co.uk/markets/Pages/sterlingoperations/timeline/ timeline_no_flash.aspx [Last accessed 3 April 2013].

Batiz-Lazo, B, Wood, D 2002 An Historical Appraisal of Information Technology in Commercial Banking. Electronic Markets, 12(3): 192-205. DOI: http://dx.doi. org/10.1080/101967802320245965

Battersby, R (dir.) 1964 Men and Money: The Stockbroker's World. BBC 2.

Buchanan, C, Crowther, S G 1963 Traffic in towns: a study of the long term problems of traffic in urban areas: reports of the Steering Group and Working Group appointed by the Minister of Transport. London: HMSO.

Burn, G 1999 The State, the City and the Euromarkets. Review of International Political Economy 6: 225-261. DOI: http://dx.doi. org/10.1080/096922999347290

Castells, M 1989 The Informational City: Information Technology, Economic Restructuring, and the Urban-Regional Process. London: Blackwell.

Chandler, E G 1975 A Working Walking City: RIBA Conference Feature. Building, 25 July.

Cheque and Credit Clearing Company n.d. 'The clearings - Early days' [WWW Document]. URL http://www.chequeandcredit. co.uk/cheque_and_credit_clearing/ history_of_the_cheque/the_clearing_-_ early_days/ [Last accessed 31 January 2013].

City of London Corporation n.d. 'Keeping the City running' [WWW Document]. URL http://www.cityoflondon.gov.uk/about-
the-city/what-we-do/Pages/keepingthe-city-running.aspx [Last accessed 17 November 2013].

City of London Department of Architecture and Planning 1976 City of London development plan: background study summary: economic activity. London: Corporation of London.

City of London Department of Architecture and Planning 1978 City of London development plan: background study sum mary: walkways \& pedestrians. London: Corporation of London.

City of London Department of Architecture and Planning 1979 City of London development plan: background study summary: environmental quality. London: Corporation of London.

City of London Department of Architecture and Planning 1984 Draft local plan: written statement and proposals map. London: Corporation of London.

City of London Department of Planning 1995 City of London Monitoring Report, 1986-1993: an analysis of the policies and context of the City of London Local Plans. London: Corporation of London.

Clark, R T 1984 Electronic funds transfer: The creeping revolution Telecommunications Policy 8(1): 29-43. DOI: http://dx.doi. org/10.1016/0308-5961(84)90057-0

Coaffee, J 2009 Terrorism, Risk and the Global City: Towards Urban Resilience. London: Ashgate.

Courtney, C, Thompson, P 1996 City lives: the changing voice of British finance. London: Methuen.

Dennis, J 2002 Britain's biggest robberies The Guardian, 18 February.

Economists Advisory Group 1971 An ECOnomic Study of the City of London. London: Allen and Unwin.

Ferris, P 1960 The City. Letchworth: Victor Gollancz.

Great Britain 1967 City of London (Various Powers). Bill with respect to City Walkways.

Hailey, M J, Wanley, J 1973 Report to the Working Group on the Automation of Money Transfer and Settlement Procedures 
between Financial Institutions in the City. The "CHAPS" Working Group. London: Interbank Research Organisation.

Hebbert, M 1993 The City of London Walkway Experiment. Journal of American Planning Association, 59(4): 433-450. DOI: http:// dx.doi.org/10.1080/01944369308975898

Hennessy, E 1992 A Domestic History of the Bank of England, 1930-1960. Cambridge: Cambridge University Press. DOI: http:// dx.doi.org/10.1017/CBO9780511896156

Holden, C, Holford, W 1951 The City of London: a record of destruction and survival; the proposals for reconstruction as incorporated in the final report of the planning consultants, C.H.Holden and W.G.Holford, presented, in 1947, to the Court of Common Council. London: Architectural Press.

Kaika, M 2010 Architecture and crisis: reinventing the icon, re-imag(in)ing London and re-branding the City. Transactions of the Institute of British Geographers, 35(4): 453-474. DOI: http://dx.doi.org/ 10.1111/j.1475-5661.2010.00398.x

King, A D 1990 Global Cities: post-imperialism and the internationalization of London. London: Routledge.

Kynaston, D 2000 The City of London, Volume 4: A club no more, 1945-2000. London: Chatto \& Windus.

Kynaston, D 2011 The City of London: the history. London: Chatto \& Windus.
Mollan, S, Michie, R 2012 The City of London as an International Commercial and Financial Center since 1900. Enterprise and Society, 13(3): 538-587. DOI: http:// dx.doi.org/10.1093/es/khr072

Moran, M 2003 The British regulatory state: high modernism and hyperinnovation. Oxford: Oxford University Press. DOI: http://dx.doi.org/10.1093/ 0199247579.001.0001

Nevin, E 1970 The London clearing banks. London: Elek Books.

\section{Progress and Tradition: Electronic Robots} 1960. The Times, 24 October, p.3.

Pryke, M 1991 An international city going "global": spatial change in the City of London. Environment and Planning D: Society and Space, 9(2): 197-222. DOI: http://dx.doi.org/10.1068/d090197

Simmel, G 1990 The Philosophy of Money. Translated by Frisby, D. and Bottomore, T. London: Routledge.

Smith, D 1991 The Rise and Fall of Monetarism. London: Penguin.

Smith, R B 1970 A Piece of Paper. The Business Lawyer, 25(3): 923-930.

Thrift, N 1994 On the social and cultural determinants of International Financial Centres: the case of the City of London. In: Thrift, N Corbridge, S Martin, R (eds.) Money, Power and Space. Oxford: Blackwell.

How to cite this article: Thomas, A 2014 Money Walks | The Economic Role of the Street in the City of London 1947-1993. Opticon1826, (16): 20, pp.1-15, DOI: http://dx.doi.org/10.5334/opt.bl

Published: 15 October 2014

Copyright: ๑ 2014 The Author(s). This is an open-access article distributed under the terms of the Creative Commons Attribution 3.0 Unported License (CC-BY 3.0), which permits unrestricted use, distribution, and reproduction in any medium, provided the original author and source are credited. See http://creativecommons.org/licenses/by/3.0/. 